FELIX BAYODE OKE

DOI: 10.15290/CR.2021.32.1.01

Anchor University, Lagos State, Nigeria

ORCID: 0000-0002-8577-224X

EZEKIEL OPEYEMI OLAJIMBITI ${ }^{1}$

Federal University Lokoja, Nigeria

ORCID: 0000-0002-5263-0149

\title{
The pragmatics of promotional features and discourse strategies in postgraduate school prospectus in Nigeria
}

\begin{abstract}
This paper extends the frontier of research in the marketisation of higher education institution by investigating the pragmatics of promotional features and discourse strategies in the postgraduate school prospectus. The data for the study is the University of Ibadan postgraduate school prospectus (2015 edition) downloaded from the university website (http://www.postgraduateschool.ui.edu.ng). Insights were drawn from Bhatia's genre analysis, an aspect of Hallidayian's Systemic Functional Linguistics, for the analysis. The theory accounts for promotional features, linguistic features and discourse strategies in the discourse. Four promotional features: offer, commodification, incentives and clients were marked off by modality, epistemic and deontic linguistic features while strategies of self-promotion, implication, promotional tact and evocation to considerateness are tactfully employed to project the superiority ideology to the prospective students. The study concludes that the academia is no longer solely informative but promotionally oriented.
\end{abstract}

Keywords: commodification, marketisation, genre analysis, promotional features, evocation to considerateness.

\section{Background to the study}

Research in higher education institution (HEI) discourses has increased greatly as a result of globalisation, particularly on how universities package their programmes in form of promotional values to showcase what they offer in terms of quality and core values. Recently, attention has been paid to the marketisation of higher education from different perspectives (Bhatia 1993, 2007; Askehave 2007; Brown 2015; Kheovichai 2014;

1 Corresponding Author. Address for correspondence: Federal University Lokoja PMB 1154 Lokoja, Nigeria. E-mail: opebukola56@gmail.com 
Han 2014; Xion 2012) on institution's prospectus, websites and course contents, among others; which have been explored from the perspectives of genre analysis, CDA and educational policy. In Nigeria, to the best of our knowledge, there is little or no attention paid to the discourses of higher education as a market enterprise. The closest studies are on the aspects of abstracts and call for papers in academic genre of higher education discourse (Olaniyan 2013; Odeneye 2014). The current research does not only fill this gap but also extends the frontier of research in the marketisation of education institution by looking at the promotional features and discursive strategies in University of Ibadan postgraduate prospectus. This attempt will unearth the rhetorical features and examine the discourse strategies employed in the postgraduate prospectus as a form of marketisation. Traditionally, the university prospectus is expected to be informationally oriented as it is an academic document, but the promotional dimension projecting the marketisation of higher education has become a paradigm shift to higher education documents.

\section{Studies on Higher Education Institutions (HEI)}

Studies on higher education institutions abound, especially in international scholarship (Bhatia 1993, 2007; Askehave 2007; Brown 2015; Kheovichai 2014). Some of them are reviewed in this section to situate the present study. Askehave (2007) investigated the impact of marketisation on higher education genres using the international student prospectus. The paper highlighted the practice of marketisation at the level of discourse in higher education. From CDA and genre analysis perspectives, the study described students' prospectus as a highly promotional genre in reflecting the values and forces of free market. Through 'rhetorical moves', Askehave's paper clearly concluded that students' prospectus is used to construct both the image of the university and the students thereby presenting innovative products to demanding clients. The foregoing becomes the footing path for the present study. In his paper, Brown (2015) examined the marketisation of higher education from the policy perspective, where he considered the paradoxes in a market-driven higher education system in the United Kingdom.

Similarly, Kheovichai (2014) packaged a study on marketised university discourse by looking at the synchronic and diachronic comparison of the discourse construction of employer organisation in academic and business job advertisements. The study employed transitivity analysis and modality to point out the discursive construction of organisations in a promotional manner such as businesses, entrepreneurs, service providers and still maintaining their identity as educational institutions. In China, Han (2014) examined the concept of marketisation of public discourse using universities documents. He established through CDA and critical genre analysis that marketisation facilitates the institutional restructuring and transformation of universities in China.

While the studies reviewed above have examined the concept of marketisation in higher education institutions, the concept has not been adequately investigated in the 
Nigerian context. Few studies on educational institutions in Nigeria have captured historical, facility, programme and policy related issues (Fafunwa 1970; Ogunu 2000; Ekundayo \& Ajayi 2009). Therefore, investigating marketisation phenomenon in higher education institutions in Nigeria becomes significant because such attempt will place Nigerian higher education in the same prestige in analysing the marketing values of education content especially the higher education prospectus.

\section{Theoretical orientations}

The study draws insights from Systemic Functional Linguistics, focusing on genre analysis as representation of ideological construct. Genre analysis is a multi-disciplinary activity attracting attention from discourse analysts, communication experts and rhetoricians, linguists just to mention only a few. The theory can be defined as typifications of social and rhetorical action (Miller 1984), regularities of stages (Berkenkotter \& Huckin 1995), goal oriented social processes (Martin 1993:100), consistency of communicative purposes (Swales 1990; Bhatia 1993:15). It underscores situated linguistic behaviour. Bhatia (1993: 15) argues that "although much of the work on genre analysis has been primarily motivated by applied linguistic concerns... go beyond such concerns in an attempt to redefine the conventional boundaries of applied linguistics".

As a model, a generic description is used as a representative, typical, or ideal example of generic construct as input for learners to analyse, understand and to exploit in writing to innovate and respond to novel situations. As a resource, the focus shifts from the textual description as a model to the knowledge of procedures, practices and conventions that make the text possible and relevant to a particular socio-rhetorical context. This is similar to Halliday's (1975: 32) generic potential, which enables one to make appropriate decisions as to the choice of lexico-grammatical as well as generic resources to respond to familiar and not so familiar rhetorical situations. Genres are given typical names, yet different members of discourse communities varying perspectives on and interpretations of them, which sometimes are contested (Candlin \& Plum 1999; Bhatia 1999).

In the literature, two approaches have been identified in genre analysis: textual analysis of genres and the social context or discourse community of genre analysis (Freedman \& Medway 1994). In sum, Bhatia (2002:5), in what is considered as the goal of the theory, discusses that genres as forms of consistencies in communicative events, emphasising the amount to which the complexity of the world of discourse affects generic research. She further argued that instead of proscriptive model, generic description should be viewed as a resource for 'the knowledge' of procedures, practices, and convention that make the text possible and relevant to a particular socio-rhetorical context. Therefore, the main goals of genre theory are: to represent and account for the seemingly chaotic realities of the world, to understand and account for the private intentions of the author, in addition to socially recognised communicative purposes, to understand how 
language is used shaped by socio critical environment and to offer effective solutions to pedagogical and other applied linguistic problems.

\section{Methodology}

The data for the study is the University of Ibadan postgraduate school prospectus (2015 edition) downloaded from the university website (http://www.postgraduateschool.ui.edu.ng). The University of Ibadan, established in 1948, is located in Ibadan, Oyo State Nigeria. It is known as the Premier University, being the first university in the nation and one of the leading universities in Africa. The University postgraduate school is the largest in Africa and the flagship of postgraduate education in Nigeria, as it produces the much required human resources for the entire Nigerian university system. The prospectus is written in English as it targets both Nigerians and foreign prospective students. Only three broad sections of the prospectus were sampled for analysis. They are: introduction, admission requirements and guidelines for filling application forms. These sections were purposively selected with emphasis on both sub-headings and contents because they constitute relevance to the objective of the study. Insights were drawn from genre analysis to drive home the study's objectives. As well, the study adopted descriptive research design to handle the qualitative nature of the research in a discourse-pragmatic approach. This methodology accounts for promotional features, linguistic features and discursive strategies in UIPGSP.

\section{Analysis and findings}

The analysis interfaced promotional features, discourse strategies and ideological implications as identified in the University postgraduates Prospectus. The promotional features which are captured in advertising genre are similarly identified in academic genre as offer, commodification, incentives and clients. These suggest a blend of academic and advertising genres with a view to promoting the flagship of postgraduate education (as claimed by the UIPG prospectus). Traditionally, university prospectus is expected to be formally informative but due to competitive market, the university employs advertising genres designed to 'sell' the university to potential applicants (Askehave 2007). Hence, the primacy for promotional function in academic genre as a blend of two genres; academic and advertising is important to meet up with contemporary realities. This study identified four promotional features in the sampled prospectus: offer, commodification, incentives and clients. They are discussed in turns.

\section{Offer}

Offer relates to the presentation of what an organisation or institution does in terms of services or products for the interest of those that would like to have them or use them. Through an offer, buyers manifest a desire to buy whatsoever is packaged by the seller. 
In higher education discourse, an institution is seen as the seller of programmes while the students are the buyers. The offer in this regard is presented in different forms and layers to appeal, persuade and convince the buyer of the good product, that is, what the institution wants to offer the prospective students. These stages are presented in the University of Ibadan postgraduate school student prospectus sections on introduction, admission types and application forms. The excerpts below exemplify this.

\section{Excerpt 1}

Today, the University has a total enrolment of about 20,000 students shared among different faculties... About $40 \%$ of the enrolment is postgraduate students

\section{Excerpt 2}

\section{AVAILABLE RESEARCH DEGREE PROGRAMMES}

(a) Doctor of Philosophy (Ph.D), Master of Philosophy (M.Phil), Master of Public Health (M.P.H.), Degree of Master (M.A., M.Sc., M.Ed, LL.M), These are available in the following Faculties and disciplines:

The texts in (1) and (2) describe what the university does and offers the general public. (1) captures what the university is capable of doing, by proudly stating that forty percent of the entire enrolment is postgraduate students. This gives credence to the chances of any interested member of the public in the offer. To specify what the institution offers, the prospectus states the available research degree programmes (ARDP) in (2) above. Two contexts best described the contents of (1) and (2) as offers. They are contexts of education and marketing. These two broad contexts represent two different perspectives but are recontextualised to draw symbiotic relationships of the two perspectives.

In textual analysis of the prospectus, the grammatical aspect focuses on the clausal elements with emphasis on the features of modality. Modality system construes the region of uncertainty that lies between 'yes' or 'no'. Three modal features are exemplified in the text, namely, probability (epistemic), obligation (deontic), and ambivalence (mixing 'possibility' with 'permission'). There are instances of high-affinity epistemic modalities expressed as lexical verbs modals. Also, the deontic modalities expressing obligational meaning of the modal verbs are prevalent. In instantiating modality features in the text, modal operators are used. The entry for this prospectus has some major contents. Specifically, meanings of requirement and obligation and formal lexical realisations are significant to the promotional features. In the entry column, the introduction section orients to providing the applicants with a clear and first-hand information about the university such as founding year, students enrolment, high ranking, etc. The lexical features employed at the clause level provide the applicants with the following: 
i. that the university is the first higher educational institution in Nigeria (The University of Ibadan was founded in 1948...),

ii. that the university operates autonomously outside the University College London in 1962

iii. the number of enrolment geometrically rates 20,000 students with $40 \%$ postgraduate students today,

iv. above all, the high ranking of the university indexed her to be the best in Nigeria and Africa.

Two promotional features characterise the introductory entry, namely, offer and incentives. The university through the information provided offers the applicants a wide range of opportunities if they apply for any programme. The university explicitly 'sell' the name of the school, her achievements and the benefits the applicants stand to gain. Besides, the positioning and arrangement of entries in the prospectus put the 'buyer' to read this section first thereby packaging the 'product' to meet the desire and demand of the 'buyer'.

Also, the product, that is, the degree programmes serves as offer from the university. This is based on the academic needs of the applicants for postgraduate studies. This entry, though with phrases and minor clauses, lacks overt or explicit obligatory meanings (These are available in the following Faculties and disciplines) as well as backgrounds requirement. The strategy deployed here is self-promotional strategy. This relates to self-evident by stating what one has capacity to do drawing inferences to antecedent. Self-promotional involves self-praise in advertising goods and services and in this case, how the University of Ibadan postgraduate school pontificates achievement as an evidence of what it can offer the potential or prospective students.

\subsection{Commodification}

This implies the literal transformation of things into commodities. To commodify means to make commercial something that was not thought of as a product; i.e. how they are subjected to monetary value or made available for the public. It is a marketing strategy, a monetisation of different spheres. Here we consider how the university commodifies the programmes it offers: available of research degree programmes- areas of specialisation and admission requirement, method of application; available professional degree programmes, admission to higher degrees and postgraduate degrees and areas of specialisation.

\section{Excerpt 3}

\section{APPLICATION FORMS}

Requests for application forms into higher degree programmes of the University are normally made every year. The procedure for obtaining Application Forms is available at www.pgschool.ui.edu.ng. 
Application forms cost N15,000 for academic programmes and N18,000 for professional programmes. Applicants for the degree of Master and Postgraduate Diploma are to pay an extra \#2,500:00 for test of proficiency in English Language.

The text in (3) captures the commodification of the entry criterion which is the application form. As the practice in the context of marketing, the university makes public the prices of application forms for different programmes she offers. The commodities that are on sale here are the application forms thereby blending the contexts of education with context of marketing in order to make money from what the university offers.

The section of guidelines for filling application forms is considered here in the prospectus entry. This section situates the promotional features of commodification in university prospectus. The commodity for sale, that is, the degree programmes is presented as services in monetary form in which applicants/buyers could easily access. The obligational meanings are nominalised (Requests for application forms into higher degree programmes of the University are normally made every year). The passive verb is agentless with the nominalisation (requests) so that the potential applicants are absent.

With reference to the cost of purchasing the forms, the overt representation of prices for each programme becomes a matter of advertising genre. Instead, the lexical verb 'cost' may be worded to be 'may cost', an explicit obligational meaning with backgrounded requirement by the applicants. Also, the agentless passive verb (Applicants for the degree of Master and Postgraduate Diploma are to pay an extra \#2,500:00 for test of proficiency in English Language) does not present the institution as the agent responsible for collecting the fee as well as conducting the test.

In relation to the modality features, there is a preponderance use of obligation and permission meanings. Instances are:

i. applicants WOULD be informed electronically..., (obligation)

ii. if the Registrar of an applicant's University WILL provide an official copy to the School directly..., (obligation)

iii. applicants MUST enclose along with the application an unofficial or student's copy of the transcript..., (permission)

iv. applicants SHOULD make adequate arrangements with their Registrars to provide transcripts.... (permission)

For the first instance, the subjective obligational meaning is stated explicitly with the use of the modal verb 'would' in example 1 while the use 'must' in example 2 provides the applicants the permission to enclose a student's copy as part of the requirement. This is backgrounded. The strategy of implication (inferring to implicit information) is employed here. It captures how an institution gives implicit information about the 
commodities and such can be purchased by the interested customer. The competitiveness of postgraduate academic products by many competitors, informs why any institution for instance will make explicit information about the commodities it offers. This strategy characterises commodification feature advertised to the public; because the success of any money-mediated market is dependent on the functionally specific type of communication.

\subsection{Incentives}

Incentives are to appeal emotionally to prospective students discursively using rhetoric of corporate advertising. Here we consider benefits programmes highlighted by the prospectus such as workshops, scholarships and so on. The excerpts below explicate the promotional concept as it is practiced in advertisement.

\section{Excerpt 4}

In order to encourage postgraduate students endowed with outstanding research potentials to undertake full-time research leading to a PhD of the University of Ibadan, the Postgraduate School has established two schemes, namely:

(a) The University of Ibadan Postgraduate School Scholarship Scheme

(b) The University of Ibadan Postgraduate School Teaching and Research Assistantship Scheme

\section{Excerpt 5}

Funding Support to Academic Units for the Publication of Learned Journals; no less than 15 academic journals are supported annually

Within marketing context, incentives are forms of inducements to entice buyers. The university in the context of education adopts the practice of context of marketing to entice membersofthe publictobeinterestedinitsoffersamidstotheruniversitieswhooffersimilar services in the spirit of competition. Three incentives presented in the excerpts above are postgraduate scholarships, teaching and research assistantship and funding support.

The incentive promotional feature identified under the introductory section of the entry appeals to the applicants/buyers' emotions of what they stand to gain for their choice. Characteristically, there are instances of overt/explicit obligational meanings without requirements from the applicants. In terms of agency or authority, the university presents the applicants with potential benefits by providing funding support and scholarship. Also, their needs are attracted by the provision made and not by what the institution stands to gain. The marketing of products by the university through the instantiation of what the applicants would benefit such as scholarships, workshops and publication outlets puts the university as the service provider. The strategy that characterised this feature is promotional tact. Promotional tact entails schemes put in place by a seller or service provider to encourage, induce and motivate buyers to be interested in the offer 
of such institution. It is a packaging tact relating to the penetrative powers of the price system and the spread of analogous relations into every aspect of social life, especially of the customer. The aim is to stimulate customers to take action towards a buying decision.

\subsection{Clients}

Clients are synonymous to customers, buyers and purchasers. They are individuals who get goods and services from a professional body or an institution in exchange for payment. They are clients in the context of marketing but students or prospective students in the context of education. The excerpts below explicate this further.

\section{Excerpt 6}

THE INFORMATION CONTAINED HEREIN IS INTENDED AS A GUIDE TO PROSPECTIVE APPLICANTS FOR ADMISSION. CANDIDATES ARE ADVISED UPON ADMISSION TO CONSULT DEPARTMENTAL AND FACULTY BROCHURES AS THEY RELATE TO THEIR RESPECTIVE PROGRAMMES AND COURSES OF STUDY.

\section{Excerpt 7}

(c) A candidate MAY apply to only one department or programme.

(d) Applicants ARE TO UPLOAD their relevant credentials and SUBMIT along with their application electronically

\section{(e) Acknowledgement of Application}

Applicants WOULD be informed electronically (through the e mail addresses provided in the electronically filled Application form) of progress in the processing of their forms. To prevent delays, applicants SHOULD make adequate arrangements with their Registrars to provide transcripts before the stipulated deadline.

The excerpts above represent clients as 'candidates', 'applicants', 'prospective students'. These are the ones who patronize what the university offers. The institution offers good value and service to customers. The clients are expressed in the postgraduate school prospectus of the university.

Another section of the prospectus entry is the admission requirements as characterized through the promotional feature of client, that is, the requirements the clients/ customers/buyers/prospective students must fulfill before getting admission. In the entry, meanings of obligation and permission are utilized explicitly as exemplified through the obligation and permissive verbs (Qualified candidates with written evidence of sponsorship SHALL be given preference and Graduates of the programme WILL be equipped to work...) While the first positioned the clients (applicants) as recipients and the university as under obligation to provide the service, the agent is passive, that is, there is no mentioning of the institution who will give the preferences to the candidate. Another 
instance is the second modal 'will' with the implicit obligational meaning of who equips the candidates. Emphasis is on the benefits/gains of the clients.

In the same vein, the obligational meanings of modal features extend to that of permission with the permissive verbs of 'will'. The institution being the implicit agent permits the applicants referred to as beneficiary from the programme in these two instances (...the applicant WILL be able to pursue creditably a programme... and Students WILL also be expected to register on the University of Ibadan website simultaneously).

Instances of ambivalence of modal features occur in the entry. The use of the epistemic or probability (Final selection WILL be based on written examination and oral interview of short-listed candidates) provides the applicants with the knowledge established by the institution on the selection process but backgrounds implicitly the agent (institution) who conducts the examination. Also, the use of possibility (but with recognised equivalent professional membership MAY be considered for admission) places the applicants in a near-reality of seeking admission without any binding role on the institution. Evocation to considerateness is the strategy that marks off this feature. It connects to the attitude of being customer friendly. It essentialises how service providers or sellers project certain considerations towards their prospective buyers. This strategy marks off how the University of Ibadan Postgraduate school prospectus relates with prospectus students as clients; as such evoking to the nature of being considerate as to encourage them to prioritize the institution over others.

Essentially, the foregoing characterise superiority ideology as the University positions herself better than other universities; thereby making her product the best to be patronised by the general public especially prospective students. This is projected in this "...above all, the high ranking of the university indexed her to be the best in Nigeria and Africa". Claiming to be the best University in Nigeria and Africa is a way of asserting superiority over universities in terms of what she offers. This ideological construct seems important because of the competitiveness of postgraduate education among Nigerian universities. Therefore, information packaging in showcasing what a particular university can offer prospective students determines the patronage such a university would get eventually.

\section{Conclusion}

This study has critically identified promotional features as forms of marketisation in academic discourse. The prospectus provides applicants with vital information through the classification or division of entries but this process now manifests high sense of advertisement aptly characterised through the promotional features of offer, incentives, commodification and clients. These are further instantiated by modality features of obligation (deontic), probability (epistemic), and ambivalence (possibility and permission). Proportionately, the discursive promotional strategies of self-promotion, 
implication, promotional tact and evocation to considerateness deployed underpin the prominence of careers information on the production of prospectus. The preponderance use of obligational meanings portrays the institution has authority (agent) that provides information on a take-it-or-leave-it basis. Also, the entrepreneurial institutional identity through the incentives and offers strategically places the institution as the best choice over others in terms of research and human capacity development.

In sum, the discourse of prospectus genre considered is an admixture of the traditional informationally oriented genre and that of advertising. Through this, the institutional goals and objectives are achieved by giving primacy to the promotional function of advertising which is designed to 'sell' the university to potential applicants even in a competitive market. It also situates the institution on prestige or corporate promotion.

\section{References}

Askehave, I. 2007. The impact of marketization on higher education genres - the international student prospectus as a case in point. Discourse Studies 9 (6): 723-742.

Bhatia, V. K. 1993. Analysing Genre: Language Use in Professional Settings. London: Longman.

Bhatia, V. K. 1999. Integrating products, processes, purposes and participants in professional writing. In: C. N. Candlin \& K. Hyland (eds.), Writing: Texts, Processes and Practices, 21-39. London: Routledge.

Bhatia, V. K. 2002. Applied genre analysis: A multi-perspective model. AELFE 4: 3-19. Bhatia, V. K. 2011. A generic view of academic discourse. In: V. K. Bhatia (ed.), Academic Discourse, 31-49. London: Routledge.

Brown, R. 2015. The marketization of higher education: issues and ironies. Higher Education Policy 1(1): 1-9.

Candlin, C. N. \& Plum, G. A. 1999. Engaging with challenges of interdiscursivity in academic writing: researchers, students and tutors. In: C.N. Candlin \& R. Hyland (eds.), Writing: Texts, Processes and Practices, 193-217. London: Routledge.

Ekundayo, H. T. \& Ajayi, A. I. 2009. Towards effective management of university education in Nigeria. International NGO Journal 4 (8): 342-347.

Fafunwa, A. B. 1970. A History of Nigerian Higher Education. Lagos: Macmillan.

Fairclough, N. 1993. Critical discourse analysis and the marketization of public discourse: The Universities. Discourse and Society 4(2): 133-168.

Halliday, M.A.K. 1975. Learning How to Mean. Explorations in the Development of Language. London: Edward Arnold.

Han, Z. 2014. The marketization of public discourse: the Chinese universities. Discourse and Communication 8(1): 85-103. 
Kheovichai, B. 2014. Marketized university discourse: a synchronic and diachronic comparison of the discursive constructions of employer organisations in academic and business job advertisement. Discourse and Communication 8(4): 371-390.

Martin, J. R. 1992. English Text: System and Structure. Amsterdam: John Benjamins.

Martin, J. R. 1993. A contextual theory of language. The Powers of Literacy - A Genre Approach to Teaching and Writing. Pittsburgh: University of Pittsburgh Press.

Miller, C. R. 1984. Genre as social action. Quarterly Journal of Speech 70: 151-167.

Ogunu, M. 2000. Introduction to Educational Management. Benin City: Mabogun Publishers.

Okemakinde, T. 2014. Transformation of higher education towards enhanced quality education in Nigeria. European Journal of Humanities and Social Sciences 29 (1): 35-47.

Swales, J. 1990. Genre Analysis: English in Academic and Research Settings. Cambridge: Cambridge University Press.

Swales, J. 2004. Research Genres - Explorations and Applications. Cambridge: Cambridge University Press.

Xion, T. 2012. Discourse and marketization of higher education in China: the genre of advertisement for academic posts. Discourse and Society 23(3): 318-337.

$* * *$

Felix Bayode Oke is a doctoral student in the University of Ibadan and a lecturer in the Department of Languages, Anchor University, Ayobo, Lagos State, Nigeria. He has published a number of peer-reviewed articles in his area of scholarship in reputable journals.

Ezekiel Opeyemi Olajimbiti (PhD) teaches in the Department of English and Literary Studies, Federal University Lokoja, Kogi State, Nigeria. He is a member of professional bodies such as Pragmatics Association of Nigeria (PrAN), English Scholars' Association of Nigeria (ESAN) and others. He specialises in children's representation in the media, media studies and political discourse. He has published in reputable journals. His research interest covers pragmatics, discourse analysis, semantics and sociolinguistics. 